\title{
Mechanisms of oxidative stress and alterations in gene expression by Libby six-mix in human mesothelial cells
}

Jedd M Hillegass', Arti Shukla', Maximilian B MacPherson', Sherrill A Lathrop', Vlada Alexeeva', Timothy N Perkins' ${ }^{1}$, Albert van der Vliet ${ }^{1}$, Pamela M Vacek ${ }^{2}$, Mickey E Gunter ${ }^{3}$, Brooke T Mossman ${ }^{1 *}$

\begin{abstract}
Background: Exposures to an amphibole fiber in Libby, Montana cause increases in malignant mesothelioma $(\mathrm{MM})$, a tumor of the pleural and peritoneal cavities with a poor prognosis. Affymetrix microarray/GeneSifter analysis was used to determine alterations in gene expression of a human mesothelial cell line (LP9/TERT-1) by a non-toxic concentration $\left(15 \times 10^{6} \mathrm{\mu m}^{2} / \mathrm{cm}^{2}\right)$ of unprocessed Libby six-mix and negative (glass beads) and positive (crocidolite asbestos) controls. Because manganese superoxide dismutase (MnSOD; SOD2) was the only gene upregulated significantly $(p<0.05)$ at both 8 and 24 h, we measured SOD protein and activity, oxidative stress and glutathione (GSH) levels to better understand oxidative events after exposure to non-toxic $\left(15 \times 10^{6} \mathrm{\mu m}^{2} / \mathrm{cm}^{2}\right)$ and toxic concentrations $\left(75 \times 10^{6} \mu \mathrm{m}^{2} / \mathrm{cm}^{2}\right)$ of Libby six-mix.

Results: Exposure to $15 \times 10^{6} \mathrm{\mu m}^{2} / \mathrm{cm}^{2}$ Libby six-mix elicited significant $(p<0.05)$ upregulation of one gene (SOD2; 4-fold) at $8 \mathrm{~h}$ and 111 gene changes at $24 \mathrm{~h}$, including a 5-fold increase in SOD2. Increased levels of SOD2 mRNA at $24 \mathrm{~h}$ were also confirmed in HKNM-2 normal human pleural mesothelial cells by qRT-PCR. SOD2 protein levels were increased at toxic concentrations $\left(75 \times 10^{6} \mathrm{\mu m}^{2} / \mathrm{cm}^{2}\right)$ of Libby six-mix at $24 \mathrm{~h}$. In addition, levels of copper-zinc superoxide dismutase (Cu/ZnSOD; SOD1) protein were increased at $24 \mathrm{~h}$ in all mineral groups. A dose-related increase in SOD2 activity was observed, although total SOD activity remained unchanged.

Dichlorodihydrofluorescein diacetate (DCFDA) fluorescence staining and flow cytometry revealed a dose- and timedependent increase in reactive oxygen species (ROS) production by LP9/TERT-1 cells exposed to Libby six-mix. Both Libby six-mix and crocidolite asbestos at $75 \times 10^{6} \mu \mathrm{m}^{2} / \mathrm{cm}^{2}$ caused transient decreases $(p<0.05)$ in GSH for up to $24 \mathrm{~h}$ and increases in gene expression of heme oxygenase 1 (HO-1) in LP9/TERT-1 and HKNM-2 cells.

Conclusions: Libby six-mix causes multiple gene expression changes in LP9/TERT-1 human mesothelial cells, as well as increases in SOD2, increased production of oxidants, and transient decreases in intracellular GSH. These events are not observed at equal surface area concentrations of nontoxic glass beads. Results support a mechanistic basis for the importance of SOD2 in proliferation and apoptosis of mesothelial cells and its potential use as a biomarker of early responses to mesotheliomagenic minerals.
\end{abstract}

\section{Background}

Asbestos is a commercial designation for a group of six mineral fibers that have been used in commerce and industry for decades [1]. Although asbestos is no longer used in building materials in the United States, health hazards associated with various types of asbestos,

\footnotetext{
* Correspondence: brooke.mossman@uvm.edu

'Department of Pathology, University of Vermont College of Medicine, 89 Beaumont Avenue, Burlington, VT 05405, USA

Full list of author information is available at the end of the article
}

especially amphibole types that give rise to the devastating cancer malignant mesothelioma (MM), remain a major concern in many countries [2]. Substantial quantities of commercial asbestos and other minerals, such as vermiculite that contains trace amounts of an amphibole fiber, remain in waste piles and buildings at several sites. The mine in Libby, Montana is of particular interest given that at one time it produced up to $80 \%$ of the world's supply of vermiculite [3], and exposure occurred outside of Libby at numerous processing plants throughout the United States

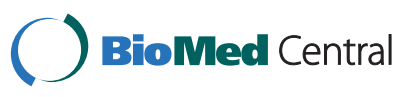


[4]. Additionally, it is estimated that nearly 1 million homes in the United States have expanded vermiculitebased insulation [5]. Although technically not classified as one of the six types of asbestos, exposure of residents and past workers at the vermiculite mine to Libby six-mix has been associated with the development of pleural plaques [6] and numerous asbestos-related diseases including asbestosis, pleural fibrosis and MMs, respectively [7-11]. In fact, standardized mortality rates from asbestosis in this region, including those of miners, are reported to be 40 to 80 times greater than expected when compared to the reference populations in Montana and the United States, respectively [12]. Lung cancer mortality is also elevated in these individuals compared to the remainder of the United States [13].

The specific mechanisms whereby asbestos causes cellular injury are not completely understood, although they are believed to involve the generation of reactive oxygen species (ROS) from cells or from reduction-oxidation reactions occurring on the surface of high iron-containing fibers (reviewed in [14]). It is unclear whether Libby six-mix has the same molecular and pathogenic effects on cells of the lung and pleura as do amphibole types of asbestos such as crocidolite. Here we used gene expression profiling to define early molecular events occurring in the human mesothelial cell line, LP9/TERT-1, that may contribute to the toxicity of Libby six-mix. Our laboratory has recently utilized this approach to examine transcriptional alterations in LP9/TERT-1 cells following exposure to crocidolite asbestos, nonfibrous talc, fine titanium dioxide (TiO2), or glass beads $[15,16]$. Our ongoing hypothesis for both the previously reported studies and those discussed here is that the number and magnitude of significant gene changes elicited by minerals correlate with their toxicity and pathogenic potential $[15,16]$. Results of the current studies in LP9/TERT-1 cells appear to support this hypothesis.

Since microarray analyses following exposure to Libby six-mix showed that only SOD2 was upregulated at both time points tested, an observation we confirmed in isolates of HKNM-2 normal human pleural mesothelial cells, we conducted a series of experiments to examine both the potential of this amphibole to generate oxidative stress in LP9/TERT-1 cells, and the functional significance of these changes. This was especially relevant since oxidants generated by asbestos fibers or cells after contact with or uptake of asbestos are linked to toxic and biological manifestations in progenitor and effector cells of asbestos-related diseases [14]. Immunoblotting and activity assays confirmed this increase in SOD2 levels, and DCFDA fluorescence staining and flow cytometry revealed a dose- and time-dependent increase in ROS production by LP9/TERT-1 cells exposed to Libby six-mix. Given the role glutathione (GSH) plays as an antioxidant and signaling molecule in the lung, we examined the effects that Libby six-mix and crocidolite asbestos had on GSH and showed that at a toxic concentration $\left(75 \times 10^{6} \mu \mathrm{m}^{2} / \mathrm{cm}^{2}\right)$, these minerals caused transient decreases in GSH for up to $24 \mathrm{~h}$. These studies are the first to examine the ability of Libby six-mix to elicit transcriptional changes and oxidative stress in human mesothelial cells. These early molecular events may contribute to the toxicity and pre-neoplastic effects of this amphibole in the development of mesotheliomas.

\section{Results}

\section{Characterization and toxicity of mineral preparations}

Chemical composition, mean surface area (S.A.), and mean size of the glass beads, Libby six-mix and NIEHS crocidolite preparations used in our studies are provided in Table 1 and have been characterized by others [17-20]. The sample of Libby amphibole we used in the studies described here is often referred to as "six-mix" since it includes six different samples collected at the former mine site, and is comprised of a combination of several amphiboles including winchite, richterite and tremolite (approximately $84 \%, 11 \%$, and $6 \%$ of the respirable fraction, respectively), as well as other trace elements not classified in this mineral family [19]. It possesses diverse morphologies including both asbestiform and non-asbestiform structures (cleavage fragments) exhibiting a wide range of aspect ratios [21]. Trace amounts of other elements occur in NIEHS asbestos standards [22] as well as in Libby six-mix [19], and the fiber size, length and diameter distributions and proportions of cleavage fragments and nonfibrous particles are different between these preparations. For example, blocky particles and small fragments were a feature of the Libby six-mix preparation when examined by SEM (Figure 1A) as compared to fibrous crocidolite asbestos (Figure 1B). In addition, the morphology and cellular interactions of Libby six-mix with LP9/ TERT-1 cells were examined using SEM. LP9/TERT-1 cells have prominent microvilli and are squamous and contiguous, resembling the normal morphology of mesothelial cells in vivo (Figure 1C). However, treatment with $75 \times 10^{6} \mu \mathrm{m}^{2} / \mathrm{cm}^{2}$ of Libby six-mix caused contraction of the cells around long fibers, cell membrane blebbing, and exudate formation around fibers (Figure 1D). Trypan blue exclusion viability studies demonstrated a doserelated increase in cytotoxicity with increasing concentrations of Libby six-mix, but not glass beads (Figure 1E). Based on these viability studies, we chose the non-toxic Libby six-mix dose of $15 \times 10^{6} \mu \mathrm{m}^{2} / \mathrm{cm}^{2}$ with which to carry out microarray studies to avoid assaying dead or dying cells. In contrast, higher surface area concentrations $\left(75 \times 10^{6} \mathrm{\mu m}^{2} / \mathrm{cm}^{2}\right)$ of Libby six-mix and crocidolite asbestos caused approximately 60 and $50-80 \%$ decreases [16], respectively, in cell viability in LP9/TERT-1 cells at $24 \mathrm{~h}$. 
Table 1 Mineral characterization

\begin{tabular}{lllll}
\hline Name & Chemical Composition & Mean S.A. $\left(\mathbf{m}^{\mathbf{2}} \mathbf{g}\right)^{\mathbf{a}}$ & Mean Size $(\boldsymbol{\mu m})^{\mathbf{b}}$ & Source \\
\hline Glass beads & $\mathrm{SiO}_{2}$ & 3 & 2.06 & Polysciences Inc. \\
Libby six-mix & $\mathrm{See}$ references [18-20] & 5 & $7.21 \times 0.61^{\mathrm{c}}$ & USGS \\
Crocidolite & $\mathrm{Na}_{2} \mathrm{Fe}^{2+}{ }_{3} \mathrm{Fe}^{3+}{ }_{2} \mathrm{Si}_{8} \mathrm{O}_{22}(\mathrm{OH})_{2}$ & 15 & $7.40 \times 0.25$ & NIEHS Reference Sample \\
\hline
\end{tabular}

a S.A. = surface area.

${ }^{b}$ Length $\times$ diameter for Libby six-mix and crocidolite asbestos, and diameter for glass beads.

c See reference [17].

Time-related changes in gene expression are observed following exposure of LP9/TERT-1 cells to Libby six-mix GeneChip ${ }^{\oplus}$ Human Genome U133A 2.0 arrays targeting 18,400 human transcripts were used for microarray analyses of LP9/TERT- 1 cells treated with $15 \times 10^{6} \mu \mathrm{m}^{2} / \mathrm{cm}^{2}$ Libby six-mix for 8 or $24 \mathrm{~h}$. Exposure to Libby six-mix elicited upregulation of only one gene, SOD2, at $8 \mathrm{~h}$, and 111 gene changes at $24 \mathrm{~h}$. The top 10 genes upregulated or downregulated by Libby six-mix at 8 and $24 \mathrm{~h}$ are listed in Table 2. No significant $(\mathrm{p}<0.05)$ alterations in gene expression were observed following exposure to glass beads (non-pathogenic control; $75 \times 10^{6}$ $\mu \mathrm{m}^{2} / \mathrm{cm}^{2}$ ) at either time point (data not shown). Taq$\mathrm{Man}^{\odot}$ quantitative real time PCR (qRT-PCR) was employed to validate increases in ATF3, IL8, and SOD2 gene expression in HKNM-2 normal human pleural mesothelial cells. Also, since $A T F 3$ and $I L 8$ mRNA expression was increased in LP9/TERT-1 cells treated with $15 \times 10^{6} \mu \mathrm{m}^{2} / \mathrm{cm}^{2}$ Libby six-mix and in previous studies using crocidolite asbestos [16], qRT-PCR was used to verify these changes (Table 2). GeneSifter software was utilized to determine the ontology of genes upregulated and downregulated in LP9/TERT-1 cells at $24 \mathrm{~h}$. Overall, 74 genes were upregulated and 37 genes were downregulated at $24 \mathrm{~h}$ following exposure to $15 \times 10^{6} \mathrm{\mu m}^{2} / \mathrm{cm}^{2}$ of Libby six-mix (Table 3 ).

\section{SOD2 protein levels and activity are increased in LP9/ TERT-1 cells following Libby six-mix exposure}

Since SOD2 gene expression was upregulated at both $8 \mathrm{~h}$ (4-fold) and $24 \mathrm{~h}$ (5-fold), we further examined the expression of SOD protein and enzyme activity using Western blot analysis on whole-cell lysates from LP9/ TERT -1 cells exposed to glass beads (non-pathogenic

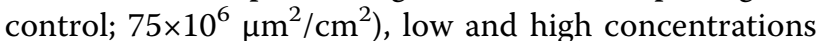
of Libby six-mix (15 and $75 \times 10^{6} \mu \mathrm{m}^{2} / \mathrm{cm}^{2}$, respectively), and the phorbol ester, TPA $(100 \mathrm{ng} / \mathrm{mL})$. At $8 \mathrm{~h}$, there were no significant $(\mathrm{p}<0.05)$ differences observed in SOD1 protein levels, and an increase in SOD2 protein was observed only in the TPA positive control treatment group (Figure 2A). At 24 h, SOD1 protein levels were significantly $(\mathrm{p}<0.05)$ higher in all treatment groups compared to the medium control group, and SOD2 protein levels were increased in high concentration Libby six-mix $\left(75 \times 10^{6} \mu \mathrm{m}^{2} / \mathrm{cm}^{2}\right)$ and TPA treatment groups (Figure 2B). Both total SOD and SOD2 activity were then examined at $24 \mathrm{~h}$ using an assay employing a tetrazolium salt which, upon reduction with superoxide anions generated via xanthine oxidase activity, forms a formazan dye. Since SOD is capable of catalyzing the reduction of superoxide anions to $\mathrm{H}_{2} \mathrm{O}_{2}$, this assay measures any changes in formazan dye formation that occurs as a result of increased/decreased SOD production following exposure to the minerals of interest. Total SOD activity was unaffected by exposure to Libby six-mix (Figure 2C). When the SOD1 and SOD3 inhibitor $\mathrm{KCN}$ was added to the reactions, a dose related increase in SOD2 activity by Libby six-mix was suggested although insignificant statistically (Figure 2D).

DCFDA assays demonstrate increased ROS production in LP9/TERT-1 cells following Libby six-mix exposure

CM- $\mathrm{H}_{2}$ DCFDA (DCFDA) is a cell permeable, fluorogenic probe that serves as an indirect indicator of intracellular ROS levels. Upon entering the cell, diacetate groups present on $\mathrm{CM}-\mathrm{H}_{2}$ DCFDA are cleaved by intracellular esterases, resulting in a reduced intermediate that can subsequently be oxidized (and thus fluoresces) in the presence of ROS. To confirm that Libby six-mix increased the production of intracellular ROS in LP9/ TERT-1 cells, this DCFDA probe was administered to cells following treatment and detected via flow cytometry or fluorescence microscopy. Flow cytometric analysis of LP9/TERT-1 cells exposed to Libby six-mix at $15 \times 10^{6}$ or $75 \times 10^{6} \mu \mathrm{m}^{2} / \mathrm{cm}^{2}$ for 8 and $24 \mathrm{~h}$ demonstrated a dose-dependent increase in relative fluorescence indicated by a log shift right ( $\mathrm{x}$-axis) in these line histograms (Figure 3A, 3B). Both cells in medium without DCFDA and cells in medium with DCFDA were included as controls. Exposure to non-pathogenic glass beads at $75 \times 10^{6} \mu \mathrm{m}^{2} / \mathrm{cm}^{2}$ had no effect on intracellular ROS production, as line histograms for this treatment group were at, or to the left of, those for the untreated control. Cells exposed to $10 \mathrm{mM} \mathrm{H}_{2} \mathrm{O}_{2}$ for $20 \mathrm{~min}$ (positive control) exhibited consistently high ROS levels at both 8 and $24 \mathrm{~h}$.

Fluorescence microscopy confirmed results obtained from flow cytometry analysis (Figure 3C). Specifically, 

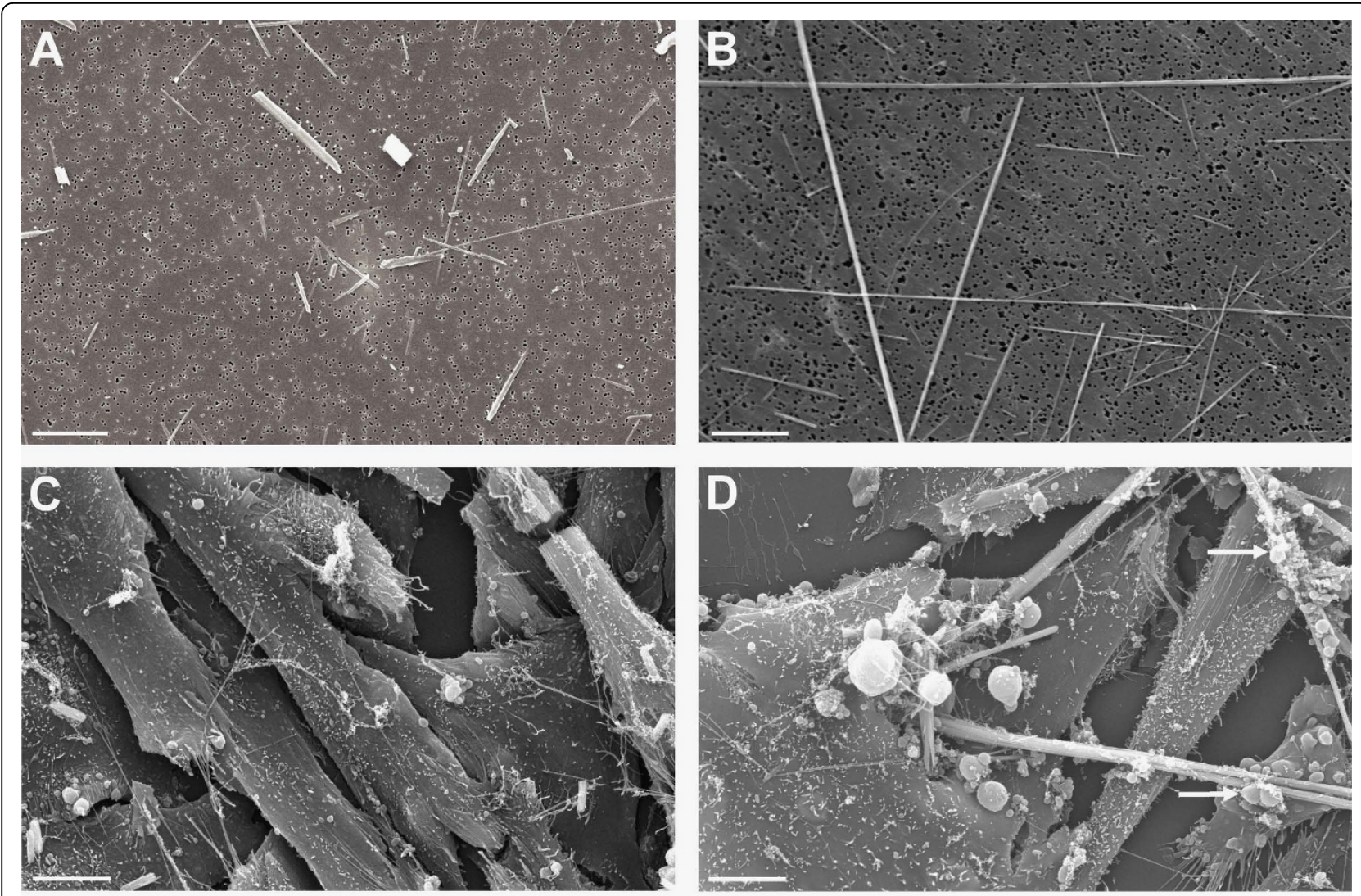

\section{$\mathbf{E}$}

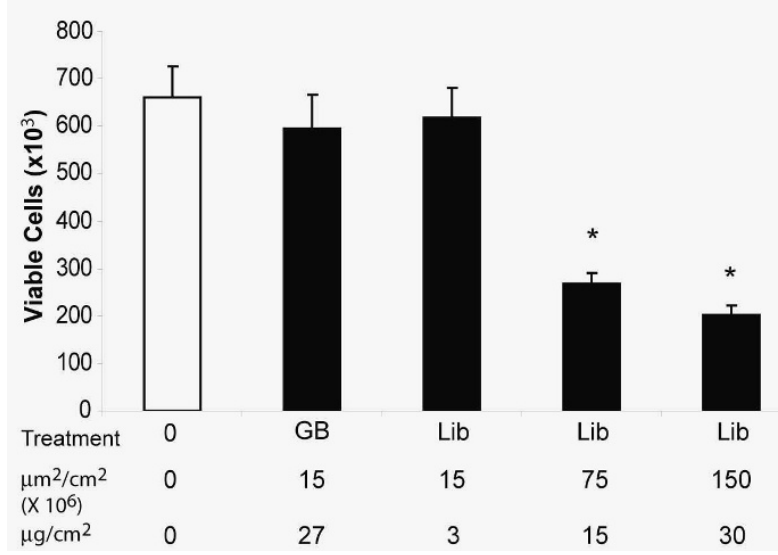

Figure 1 Interaction of Libby six-mix with LP9/TERT-1 cells and resultant changes in cell viability. SEM images of (A) Libby six-mix, (B) crocidolite asbestos, (C) LP9/TERT-1 cells alone, and (D) LP9/TERT-1 cells interacting with $75 \times 10^{6} \mathrm{\mu m}^{2} / \mathrm{cm}^{2}$ Libby six-mix. White arrows indicate cell membrane blebbing and exudate formation. All magnifications X 1500, scale bars $=10 \mu \mathrm{m}$. (E) Viability of LP9/TERT-1 cells following $24 \mathrm{~h}$ of exposure to glass beads (non-pathogenic control) or Libby six-mix as determined using $0.4 \%$ trypan blue staining of cells detached with Accutase. Bars denote the mean \pm SEM of 3 individual experiments where $n=3$ replicates per group per experiment. ${ }^{*} p<0.05$ compared to glass beads.

the $75 \times 10^{6} \mu \mathrm{m}^{2} / \mathrm{cm}^{2}$ Libby six-mix treatment group possessed a greater number of cells strongly positive for DCFDA staining compared to the medium control, glass beads, or Libby six-mix $\left(15 \times 10^{6} \mu \mathrm{m}^{2} / \mathrm{cm}^{2}\right)$ groups. Phase contrast images revealed cell piling and contraction around Libby six-mix fibers and fragments, whereas exposure to glass beads had little effect on cell morphology. When these phase contrast images were merged with images showing DCFDA fluorescence, peak levels of staining occurred in cells directly in contact 
Table 2 Top 10 gene expression alterations by Libby six-mix $\left(15 \times 10^{6} \mu \mathrm{m}^{2} / \mathrm{cm}^{2}\right)$ in LP9/TERT-1 and HKNM-2 mesothelial cells

\begin{tabular}{|c|c|c|c|c|}
\hline \multirow{2}{*}{$\begin{array}{l}\text { Gene Name (Abbreviation) } \\
\text { Increased: }\end{array}$} & \multicolumn{2}{|c|}{ Fold Change $^{a}$} & \multirow{2}{*}{$\begin{array}{l}\text { LP9/TERT-1 qRT-PCR } \\
\text { Validation }\end{array}$} & \multirow[t]{2}{*}{ HKNM-2 qRT-PCR Results ${ }^{b}$} \\
\hline & $8 \mathrm{~h}$ & $24 \mathrm{~h}$ & & \\
\hline Tissue factor pathway inhibitor-2 (TFPI2) & NC & $11^{*}$ & - & - \\
\hline Interleukin 8 C-terminal variant, 211506_s_t (IL8) & NC & $9^{*}$ & - & 3 \\
\hline Prostaglandin-endoperoxide synthase 2 (PTGS2) & NC & $7^{*}$ & - & - \\
\hline Interleukin 8 (IL8) & NC & $7^{*}$ & $14^{*}$ & - \\
\hline Pyruvate dehydrogenase kinase, isozyme 4 (PDK4) & NC & $7^{*}$ & - & - \\
\hline Pleckstrin homology-like domain, family A, member 1 (PHLDA1) & NC & $5^{*}$ & - & - \\
\hline Chemokine (C-X-C motif) ligand 3 (CXCL3) & NC & 5 & - & - \\
\hline Activating transcription factor 3 (ATF3) & NC & $5^{*}$ & $5^{*}$ & 5 \\
\hline Superoxide dismutase 2, mitochondrial (SOD2) & $4^{*}$ & $5^{*}$ & - & 2 \\
\hline \multirow[t]{2}{*}{ Annexin 14 (ANX14) } & NC & 4 & - & - \\
\hline & & & & - \\
\hline Decreased: & & & & - \\
\hline Oxytocin receptor (OXTR) & NC & $5^{*}$ & - & - \\
\hline Chromosome 5 open reading frame 13 (C5orf13) & NC & $4^{*}$ & - & - \\
\hline Chromosome 21 open reading frame 7 (C21orf7) & NC & $3^{*}$ & - & - \\
\hline Cytochrome P450, family 24, subfamily A, polypeptide 1 (CYP24A1) & NC & $3^{*}$ & - & - \\
\hline Calponin 1, basic, smooth muscle (CNN1) & NC & 3 & - & - \\
\hline Cyclin-dependent kinase inhibitor $1 C$ (CDKN1C) & NC & 3 & - & - \\
\hline Methyltransferase like 7A (METTL7A) & NC & $2^{*}$ & - & - \\
\hline Periplakin (PPL) & NC & $2^{*}$ & - & - \\
\hline Kelch-like 4 (KLHL4) & NC & 2 & - & - \\
\hline Phospholipase C-like 1 (PLCL1) & NC & $2^{*}$ & - & - \\
\hline
\end{tabular}

${ }^{\mathrm{a}} \mathrm{NC}=$ No significant $(\mathrm{p}<0.05)$ change greater than 2 -fold from untreated controls across all 3 replicates.

${ }^{b}$ HKNM-2 normal human pleural mesothelial cells were treated with $15 \times 10^{6} \mu \mathrm{m}^{2} / \mathrm{cm}^{2}$ Libby asbestos for $24 \mathrm{~h}$.

*Gene in the top 10 genes upregulated/downregulated by crocidolite asbestos at the same time and concentration [16].

with Libby six-mix fibers. A combination of DCFDA (green) and Hoechst nuclear staining (red) was then used to determine if DCFDA staining was localized to small apoptotic nuclei. As can be seen in the bottom panels of Figure 3C, DCFDA staining was not localized exclusively to cells with apoptotic nuclei in the Libby asbestos and $\mathrm{H}_{2} \mathrm{O}_{2}$ groups.
Libby six-mix and crocidolite asbestos alter mRNA levels of heme oxygenase 1 (HO-1) in LP9/TERT-1 and HKNM-2 cells

In order to further support the concept that Libby sixmix and crocidolite asbestos elicit oxidative stress in LP9/TERT-1 cells, we evaluated changes in heme oxygenase $1(\mathrm{HO}-1)$ gene expression [23] $24 \mathrm{~h}$ following

Table 3 Ontological classifications of gene expression alterations by Libby six-mix $\left(15 \times 10^{6} \mu \mathrm{m}^{2} / \mathrm{cm}^{2}\right)$ in $\mathrm{LP}^{2} / \mathrm{TERT}-1$ human mesothelial cells at $24 \mathrm{~h}$

\begin{tabular}{lll}
\hline Ontological Classification & No. Genes Upregulated & No. Genes Downregulated \\
\hline Signal transduction & 17 & 10 \\
Immune response & 8 & 1 \\
Protein metabolic process & 7 & 5 \\
Apoptosis regulation & 4 & 4 \\
Cell proliferation & 8 & 2 \\
Extracellular matrix & 2 & 1 \\
Cell adhesion & 2 & 2 \\
Cell motility & 2 & 0 \\
Oxygen \& ROS metabolic process & 1 & 0 \\
\hline
\end{tabular}

${ }^{a}$ Overall, 74 genes were upregulated and 37 genes were downregulated ( $>2$-fold compared to untreated controls; $p<0.05$ ), although only the most common ontological classifications are given. 


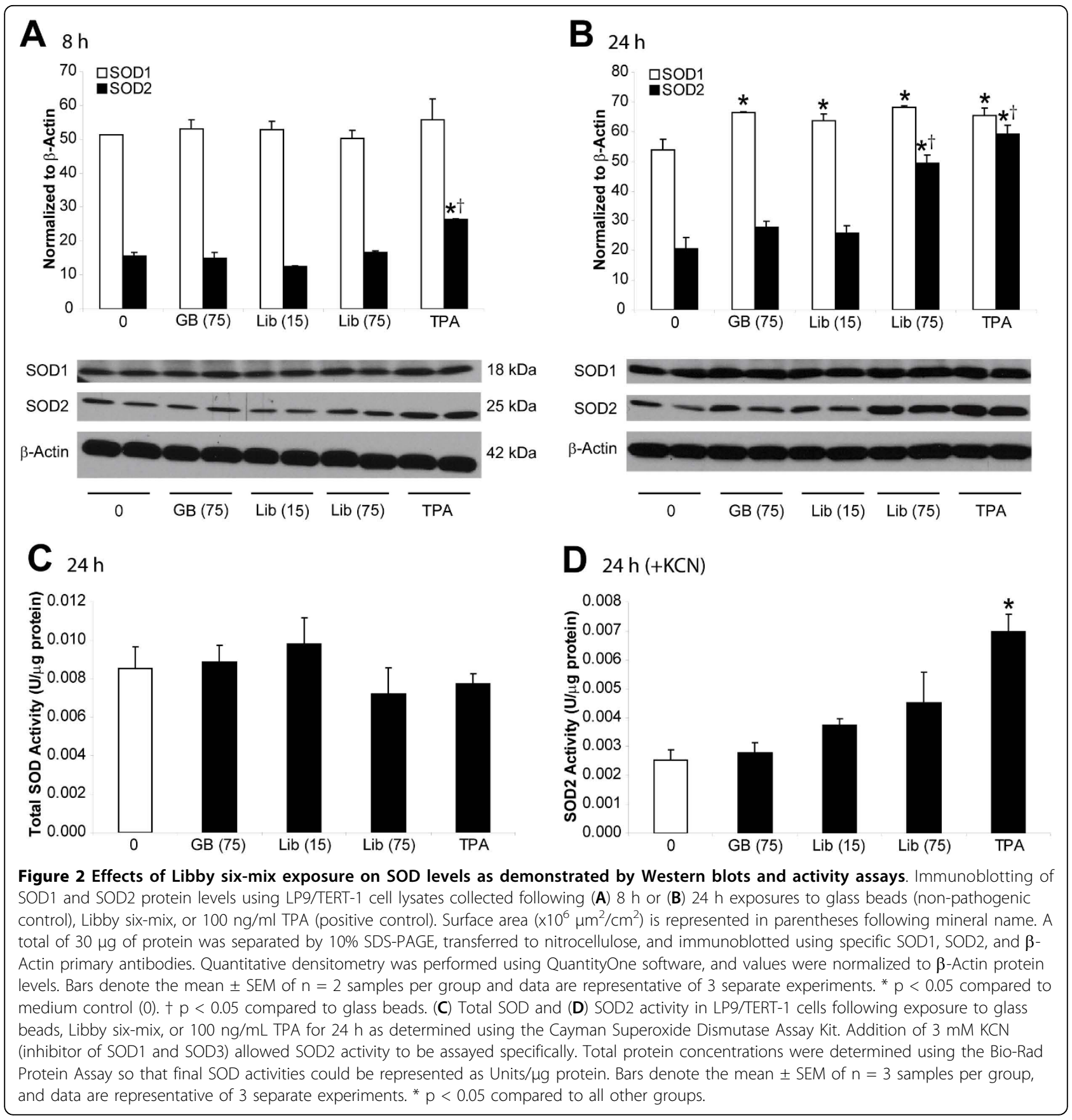

treatment with 15 or $75 \times 10^{6} \mu \mathrm{m}^{2} / \mathrm{cm}^{2}$ Libby six-mix. Libby six-mix caused a significant upregulation of $\mathrm{HO}-1$ at $75 \times 10^{6} \mu \mathrm{m}^{2} / \mathrm{cm}^{2}$ in LP9/TERT-1 cells that was not observed with identical concentrations of glass beads (GB) or at lower concentrations of Libby six-mix (Figure 4A). Although few numbers of HKNM-2 normal human pleural mesothelial cells precluded us from performing duplicate untreated control samples, the HKNM-2 cells responded similarly to LP9/TERT-1 cells in that dose-related responses were observed after exposures to Libby amphibole (Figure 4B). These results indicate that LP9/TERT-1 cells are an acceptable cell line in that they mimic normal human mesothelial cells in their responses to minerals. This fact was further substantiated by data showing that SOD2 expression in HKNM-2 cells was also significantly increased following exposure to $75 \times 10^{6} \mu^{2} / \mathrm{cm}^{2}$ of crocidolite asbestos or Libby six-mix for $24 \mathrm{~h}$ (Figure $4 \mathrm{C}$ and Table 2). 


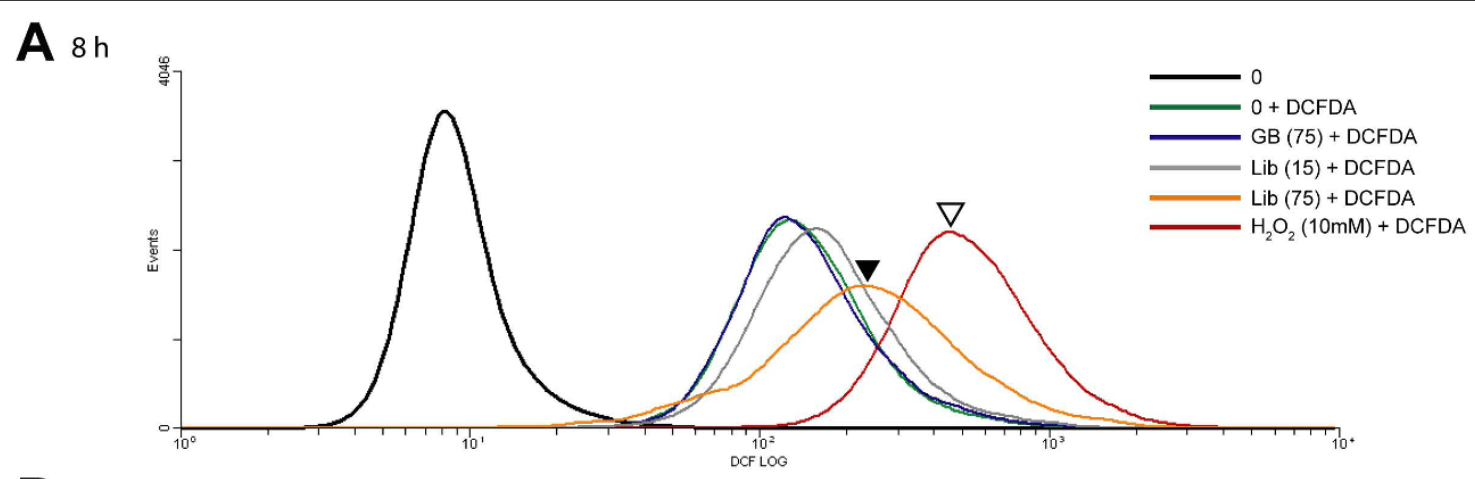

B $24 \mathrm{~h}$

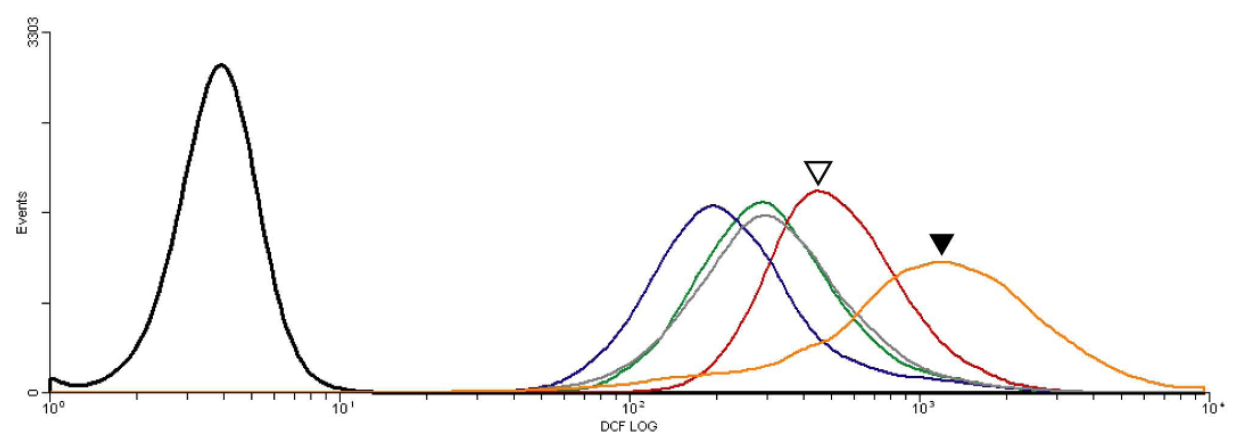

C

$0+$ DCFDA

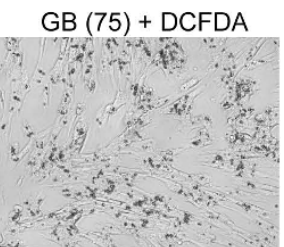

$\operatorname{Lib}(15)+$ DCFDA

$\operatorname{Lib}(75)+$ DCFDA

$\mathrm{H}_{2} \mathrm{O}_{2}(10 \mathrm{mM})+\mathrm{DCFDA}$
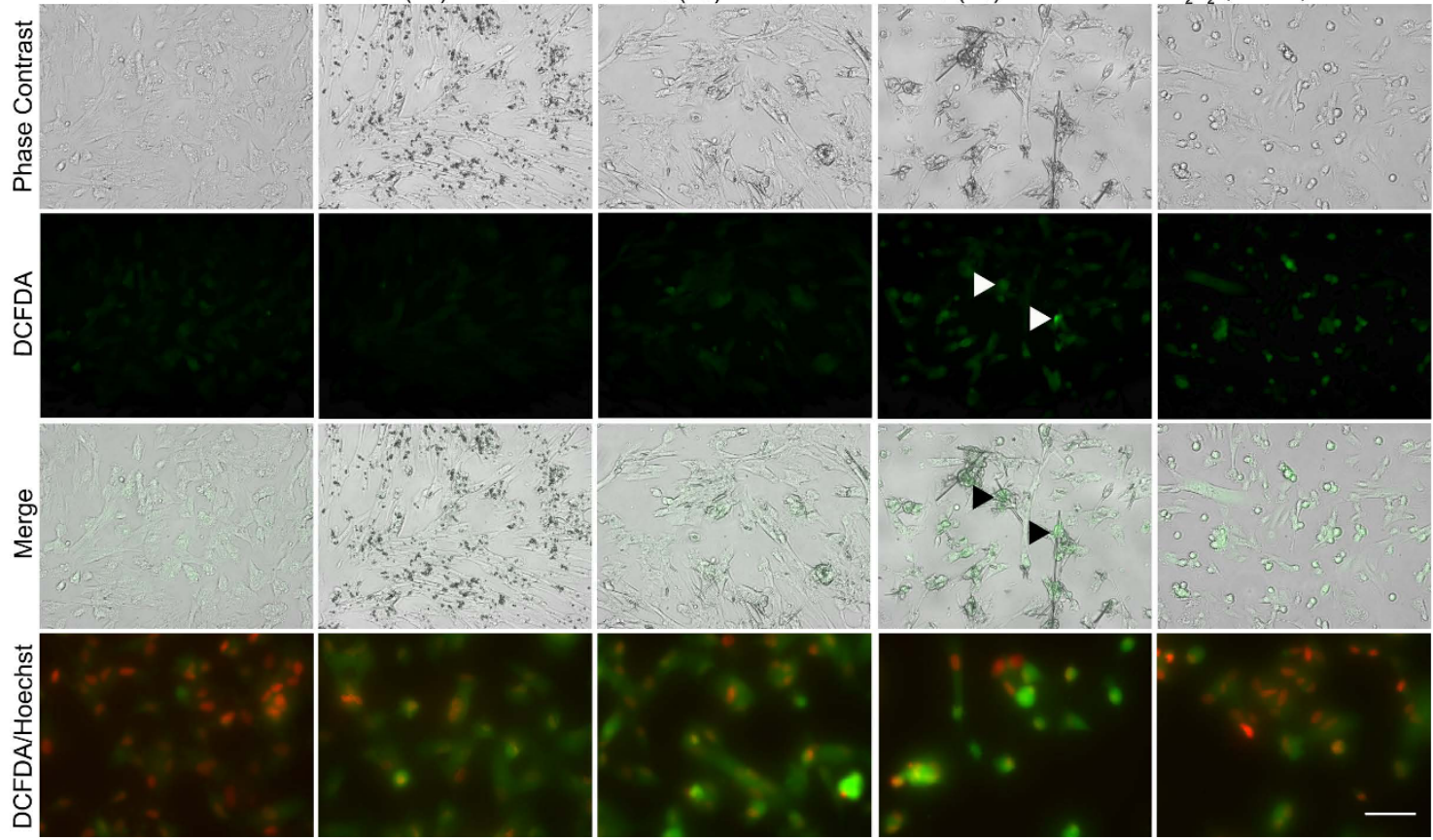

Figure 3 Determination of ROS generation via detection of DCFDA by flow cytometry and fluorescent microscopy. ROS generation in LP9/TERT-1 cells following (A) $8 \mathrm{~h}$ or (B) $24 \mathrm{~h}$ exposures to glass beads (non-pathogenic control), Libby six-mix, or $10 \mathrm{mM} \mathrm{H}_{2} \mathrm{O}_{2}$ (positive control) as determined by flow cytometric detection of DCFDA staining. White and black arrowheads indicate log shifts following exposure to $\mathrm{H}_{2} \mathrm{O}_{2}(10 \mathrm{mM} ; 20 \mathrm{~min})$ and Libby six-mix $\left(75 \times 10^{6} \mathrm{\mu m}^{2} / \mathrm{cm}^{2}\right)$, respectively. (C) DCFDA levels were also visualized using fluorescence microscopy. White arrowheads indicate increased DCFDA levels in Libby six-mix $\left(75 \times 10^{6} \mathrm{\mu m}^{2} / \mathrm{cm}^{2}\right)$ treated cells. In the merged image, black arrowheads indicate identical areas defined by the white arrowheads, and demonstrate that the highest levels of ROS are produced in areas were Libby sixmix contacts LP9/TERT-1 cells. Surface area $\left(\times 10^{6} \mathrm{\mu m}^{2} / \mathrm{cm}^{2}\right)$ is represented in parentheses following mineral name. Bottom panel shows cofluorescence of Hoechst dye (red nuclear stain) and DCFDA. Scale bar $=50 \mu \mathrm{m}$. 


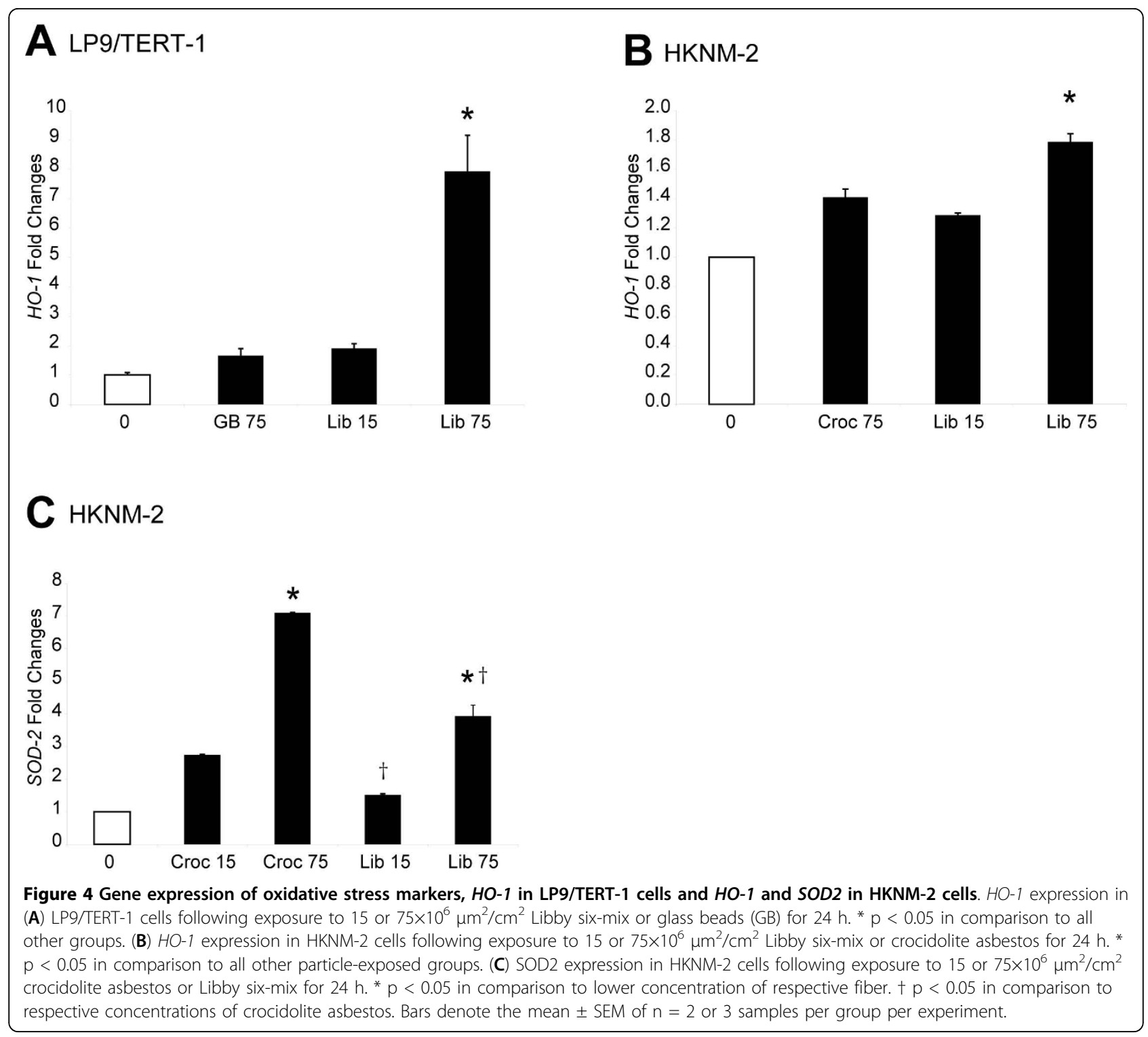

Libby six-mix and crocidolite asbestos deplete levels of reduced glutathione (GSH) in LP9/TERT-1 cells

Depletion of GSH is generally considered an indicator of oxidative stress. Since it has been demonstrated previously that crocidolite asbestos depletes intracellular GSH levels in C10 murine type II epithelial cells [24], it was included in these time course studies as a positive control. Levels of GSH in LP9/TERT-1 cells were determined by HPLC at specific time points, and data showed that exposure to Libby six-mix caused a preliminary decrease in GSH from 2 to $8 \mathrm{~h}$, followed by a progressive recovery in GSH levels through 48 h (Figure 5A). Exposure to crocidolite resulted in significant GSH depletion at all time points prior to and including $24 \mathrm{~h}$ (Figure 5B).

\section{Discussion}

Our studies are the first to use robust gene profiling to characterize alterations in gene expression in human mesothelial cells after exposure to Libby six-mix. Prior to initiating microarray studies, we determined a concentration of Libby six-mix that was not overtly toxic to LP9/ TERT-1 cells to avoid the induction of gene expression secondary to cell death. This was accomplished by performing dose-response cell viability studies where LP9/ TERT-1 cells were exposed to $15 \times 10^{6}, 75 \times 10^{6}$, and $159 \times 10^{6} \mathrm{\mu m}^{2} / \mathrm{cm}^{2}$ Libby six-mix for $24 \mathrm{~h}$. Results demonstrated that, similar to what we have reported previously for crocidolite asbestos [16], Libby six-mix caused decreases in cell viability at $24 \mathrm{~h}$ that were significant at 

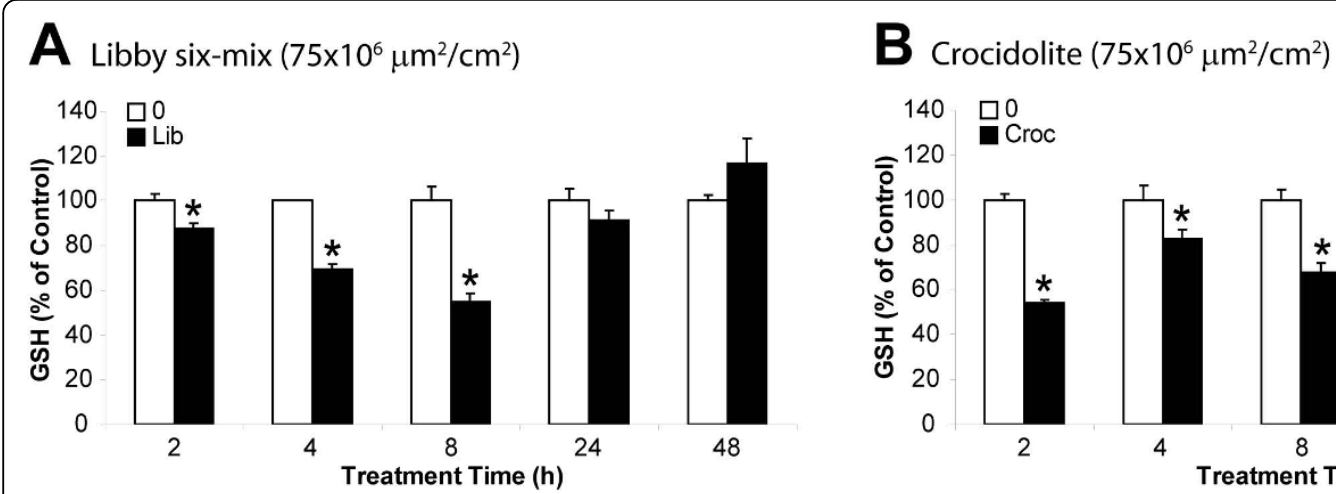

Figure 5 Effects of Libby six-mix exposure on glutathione levels in LP9/TERT-1 cells. Glutathione (GSH) levels in LP9/TERT-1 cells following exposure to (A) Libby six-mix $\left(75 \times 10^{6} \mathrm{\mu m}^{2} / \mathrm{cm}^{2}\right)$ or $(\mathbf{B})$ crocidolite asbestos $\left(75 \times 10^{6} \mathrm{\mu m}^{2} / \mathrm{cm}^{2}\right)$ as measured via HPLC over a $48 \mathrm{~h}$ period. GSH levels are defined as percent of the medium control $(0)$ at the corresponding time point. Bars denote the mean \pm SEM of $n=3$ samples per group, and data are representative of 2 separate experiments. ${ }^{*} p<0.05$ compared to medium control (0).

$75 \times 10^{6} \mu \mathrm{m}^{2} / \mathrm{cm}^{2}$ and associated with cell membrane blebbing, contraction of the cells, and exudate formation around long fibers. Based upon our toxicity data, the low $\left(15 \times 10^{6} \mu \mathrm{m}^{2} / \mathrm{cm}^{2}\right)$, nontoxic concentration of Libby sixmix and comparable surface areas of crocidolite and glass beads were chosen for microarray studies. When the top 10 gene changes following Libby six-mix exposure were compared to those reported for LP9/TERT-1 cells following crocidolite asbestos exposure at identical surface area concentrations [16], numerous similarities were observed. Libby six-mix induced significant upregulation of only one gene at $8 \mathrm{~h}$ (SOD2, 4-fold). In contrast, SOD2 (6-fold increase) was one of many genes upregulated at $8 \mathrm{~h}$ following crocidolite asbestos exposure [16]. Of the top 10 genes upregulated at $24 \mathrm{~h}$ in response to Libby six-mix, 8 were identical to those reported at $24 \mathrm{~h}$ following crocidolite asbestos exposure (TFPI2, IL8 C-terminal variant, IL8, PTGS2, PDK4, PHLDA1, ATF3, and SOD2). Similarly, 7 of the top 10 genes downregulated at $24 \mathrm{~h}$ in response to Libby six-mix were identical to those reported for crocidolite asbestos (OXTR, C5orf13, C21orf7, CYP24A1, METTL7A, PPL, and PLCL1). Gene ontology classifications for Libby six-mix also exhibited patterns similar to crocidolite asbestos whereby the most changes in expression (either upregulated or downregulated) occurred in genes associated with signal transduction, protein metabolism, cell proliferation, and immune responses [16].

Several genes upregulated in LP9/TERT-1 cells exposed to Libby six-mix or crocidolite asbestos are associated with inflammation, including the pro-inflammatory cytokine interleukin-8 (IL8). This cytokine is chemotactic for polymorphonuclear neutrophils (PMNs) and can subsequently serve as an activator for these inflammatory cells [25]. IL8 is produced by a wide array of cells including mesothelial cells, and pleural inflammation is known to be initiated by $I L 8$ secretion in response to asbestos exposure $[26,27]$. Several studies looking at serum IL8 levels in workers occupationally exposed to asbestos revealed significant increases in this cytokine $[28,29]$. Activating transcription factor 3 (ATF3), a member of the cAMPresponsive element-binding (CREB) transcription factor family encoding two isoforms leading to repression or activation of genes, was also upregulated by both Libby sixmix and crocidolite asbestos. Previous work in our laboratory has shown that silencing ATF3 in LP9/TERT-1 mesothelial cells can consequently modulate the production of several well-known asbestos-induced inflammatory cytokines and growth factors including IL-1 1 , IL-13, granulocyte colony-stimulating factor (G-CSF), vascular endothelial growth factor (VEGF), and platelet-derived growth factor-BB (PDGF-BB) [16]. Prostaglandin-endoperoxide synthase 2 (PTGS2; also known as cyclooxygenase 2 or $C O X 2)$ is an integral enzyme in the biosynthesis of prostenoids, and is implicated in carcinogenesis by modulating inflammation, mitogenesis, cell adhesion, and apoptosis. Exposure of a monocyte-macrophage (J774) cell line to an asbestos-like amphibole fiber known as fluoro-edenite induced a significant increase in PTGS2 expression [30], and immunohistochemical characterization of human MM samples demonstrated that PTGS2 was highly expressed in these tissues, but not in nonreactive mesothelial tissues from the same individuals [31]. Based upon the upregulation of these genes and others, inflammation induced in an autocrine/paracrine fashion by mesothelial cells may play a critical role in Libby six-mix and crocidolite asbestos-induced cell injury and disease.

In our studies, superoxide dismutase 2 (SOD2; manganese superoxide dismutase), a mitochondrial antioxidant protein which catalyzes the dismutation of superoxide $\left(\mathrm{O}_{2}{ }^{--}\right)$to hydrogen peroxide $\left(\mathrm{H}_{2} \mathrm{O}_{2}\right)$, was the only gene significantly upregulated by Libby six-mix and crocidolite 
asbestos at both 8 and $24 \mathrm{~h}$. This increased expression of SOD2 recapitulates previously reported data showing elevated SOD2 expression/activity in human pleural mesothelial cells or tracheal epithelial cells exposed to crocidolite or chrysotile asbestos [23,32]. The fact that SOD2 expression is upregulated following Libby six-mix and crocidolite or chrysotile asbestos exposures [23,32], likely represents activation of a defense mechanism to counteract oxidative stress induced by these fibers, specifically through the dismutation of $\mathrm{O}_{2}{ }^{--}$to $\mathrm{H}_{2} \mathrm{O}_{2}$. Increases in steady-state levels of $\mathrm{H}_{2} \mathrm{O}_{2}$ can subsequently lead to increases in cell proliferation, invasion, migration, metastasis, and resistance to apoptosis [33-35]. In addition, we have previously shown that transfection of SOD2 into rodent tracheal epithelial cells ameliorates crocidolite asbestos-induced toxicity, suggesting a role of this gene in cell survival from asbestos [36].

Elevated SOD2 levels have been observed in rodent lungs after inhalation of crocidolite asbestos $[37,38]$ and in several cancer cell types including gastric [39], colorectal [40], breast [41], and MM [42]. Based upon strong SOD2 immunoreactivity in MMs in contrast to adenocarcinomas [43], and low SOD2 levels in healthy human pleural mesothelium compared to high endogenous levels in MM lines [44], SOD2 has been proposed as a diagnostic marker for MM. Moreover, polymorphisms of glutathione-S-transferase M1 (GSTM1) and SOD2 are associated with increased risk of MM, findings contributing to the hypothesis that imbalances between oxidative stress and antioxidant enzymes are features of the pathogenesis of MM [45]. Our results showing that early increases in expression, protein levels, and activity of SOD2 occur in human mesothelial cells after exposure to MM-inducing fibers therefore may be valuable in designing predictive assays for fiber pathogenicity.

Several studies have been conducted recently examining the effects of Libby six-mix and crocidolite asbestos in tandem. For example, gene expression studies in lungs of $\mathrm{C} 57 \mathrm{Bl} / 6$ mice instilled intratracheally with Libby six-mix or crocidolite asbestos revealed common gene ontologies related to the plasma membrane, transport channels and signal transduction [46]. Lung fibrosis and collagen deposition were also observed in mice 6 months following exposure to either Libby six-mix or crocidolite asbestos, although the extent of changes observed in Libby six-mix exposed mice was consistently less [46]. A second $\mathrm{C} 57 \mathrm{Bl} / 6$ mouse study demonstrated that at 1 week, 1 month, and 3 months post intratracheal instillation of Libby six-mix or crocidolite asbestos at equal weight concentrations, both amphiboles increased the gene expression of Col1A1, Col1A2, and Col1A3, collagen protein deposition, and inflammation [47]. Again, crocidolite asbestos induced a greater response in the majority of these endpoints when compared to Libby six-mix. However, in both these experiments, an equal mass of Libby six-mix was compared to crocidolite asbestos, possibly reflecting lower fiber numbers or different length and diameter ratios of fibers per unit weight.

In vitro experiments using a murine macrophage-like cell line (RAW264.7 cells) and alveolar macrophages lavaged from $\mathrm{C} 57 \mathrm{Bl} / 6$ mice and exposed to $62.5 \mu \mathrm{g} / \mathrm{cm}^{2}$ Libby six-mix for up to $3 \mathrm{~h}$ also have shown increases in intracellular ROS levels [17]. This response was subsequently linked to increases in $\mathrm{O}_{2}{ }^{--}$by demonstrating that Libby six-mix exposure led to increased dihydroethidine (DHE) fluorescence, a probe known to preferentially detect superoxide [48]. These increases in intracellular ROS in murine macrophages resulted in oxidative DNA damage as indicated by increased relative levels of 8-oxo$\mathrm{dG}$ and the percentage of cells in the sub-G1 phase following exposure to crocidolite asbestos, but not Libby six-mix, at an equal weight concentration. Decreased intracellular GSH levels was also found to be a feature of Libby six-mix and crocidolite asbestos toxicity in this cell type [17]. On the basis of these results, the authors suggest that separate cellular responses are induced by these two minerals in vitro [17]. Although it appears from our research that similar mechanisms contribute to the toxicity of these minerals, their overall differences in toxicity and pathogenicity as demonstrated in work cited above, may reflect different numbers, sizes, and proportions of fibers to nonfibrous particles and fragments, as well as the diverse chemical composition of these different amphiboles. In our studies, oxidant generation and GSH depletion occurred only at the highest concentration of Libby six-mix where approximately $60 \%$ of cell death occurred at $24 \mathrm{~h}$. The viable cells at this time point may represent those not killed directly by oxidative stress because of intrinsically higher antioxidant defenses or cells exhibiting adaptive responses such as compensatory proliferation in response to this material. DCF fluorescence does not appear to occur coincidentally with cell death as it is often observed in non-apoptotic cells. The molecular parameters governing these responses and their relationship to cell injury and pleural disease demand further examination.

\section{Conclusions}

After addition at nontoxic concentrations to LP9/TERT-1 mesothelial cells, Libby six-mix $\left(15 \times 10^{6} \mu \mathrm{m}^{2} / \mathrm{cm}^{2}\right.$ for $24 \mathrm{~h})$ caused significant $(\mathrm{p}<0.05)$ changes in 111 genes, whereas crocidolite asbestos at identical surface area concentrations and time points caused significant changes in 205 genes [16]. No significant alterations in gene expression were observed following exposure to glass beads $\left(75 \times 10^{6} \mu \mathrm{m}^{2} / \mathrm{cm}^{2}\right)$ at either time point, establishing this material as an appropriate non-pathogenic control 
particle. Results from gene profiling studies suggest that the toxicity induced by Libby six-mix and crocidolite may be acting through a similar mechanism of action in LP9/ TERT-1 mesothelial cells. Moreover, new data here support our hypothesis that the number and magnitude of significant gene changes following exposure to pathogenic mineral fibers are indicative of their mesotheliomagenicity. Increases in SOD2 and $\mathrm{HO}-1$ gene expression were associated with increased production of oxidants and transient decreases in intracellular GSH. These results provide a mechanistic basis for the importance of SOD2 in the proliferation and apoptosis of mesothelial cells and its implementation as a potential biomarker of early responses to minerals capable of causing MM.

\section{Methods}

\section{Human Mesothelial Cell Cultures}

Human mesothelial LP9/TERT-1 cells, an hTERTimmortalized cell line phenotypically and functionally resembling normal human mesothelial cells [49], were obtained from Dr. James Rheinwald (Bringham and Women's Hospital, Boston, MA). LP9/TERT-1 cells were maintained in DMEM/F-12 (1:1) medium (Mediatech, Inc., Herndon, VA) supplemented with $10 \%$ fetal bovine serum (FBS) (Mediatech), penicillin-streptomycin (50 U/ml penicillin $\mathrm{G}, 50 \mu \mathrm{g} / \mathrm{ml}$ streptomycin sulfate) (GIBCO, Carlsbad, CA), hydrocortisone $(100 \mu \mathrm{g} / \mathrm{ml})$, insulin $(2.5 \mu \mathrm{g} / \mathrm{ml})$, transferrin $(2.5 \mu \mathrm{g} / \mathrm{ml})$ and selenium $(2.5 \mu \mathrm{g} / \mathrm{ml})$ (Sigma, St. Louis, MO). HKNM-2 normal human pleural mesothelial cells were isolated at autopsy by Dr. Helmut Popper (University of Graz, Austria) and were grown in Optimem/Hams F-12 3:1 containing 20\% FBS, EGF (20 ng/ml), insulin $(0.5 \mu \mathrm{g} / \mathrm{ml})$, hydrocortisone $(0.4 \mu \mathrm{g} / \mathrm{ml})$, penicillin $(50 \mathrm{U} / \mathrm{ml})$ and streptomycin sulfate $(100 \mu \mathrm{g} / \mathrm{ml})$ (Sigma, St. Louis, MO). Cells at near confluency were switched to maintenance medium containing $0.5 \%$ FBS overnight prior to mineral/agent exposure.

\section{Mineral Characterization}

The Libby amphibole used in these studies was obtained from the United States Geological Service (USGS) and has been physically and chemically characterized previously [18-20,50]. This sample is comprised of six different samples collected at the former Libby vermiculite mine site and is therefore termed Libby "six-mix". The physical and chemical characterization of the NIEHS reference sample of crocidolite asbestos has been reported previously as well [51]. The surface area of asbestos fibers and particles was measured using nitrogen gas sorption analysis to allow computation of identical surface area amounts of minerals to be added to cells. Fiber and particle size dimensions were determined by scanning electron microscopy (SEM) as described previously [52]. The chemical composition, surface area, mean size, and source of each mineral preparation are presented in Table 1.

\section{Introduction of Minerals/Agents to Cells}

Following sterilization under ultraviolet light overnight, minerals were suspended in 1X Hanks' Balanced Salt Solution (HBSS) at $1 \mathrm{mg} / \mathrm{ml}$, sonicated for $15 \mathrm{~min}$ in a water bath sonicator, and triturated 5 times through a 22 -gauge needle. This suspension was added to cells in medium to achieve the desired surface area-based concentrations. Phorbol 12-myristate 13-acetate (TPA; $100 \mathrm{ng} / \mathrm{ml}$ ) was used as a positive control for immunoblotting and SOD activity, and hydrogen peroxide $\left(\mathrm{H}_{2} \mathrm{O}_{2} ; 10 \mathrm{mM}\right.$ for $\left.20 \mathrm{~min}\right)$ was used as a positive control for the DCFDA assay. $\mathrm{H}_{2} \mathrm{O}_{2}$ (Sigma, St. Louis, MO) was added directly to the medium and TPA (Sigma, St. Louis, MO) was dissolved in dimethylsulfoxide (DMSO) prior to addition to the medium.

\section{Scanning Electron Microscopy (SEM)}

For imaging Libby six-mix and crocidolite asbestos alone, 0.0027 or $0.0023 \mathrm{~g}$ was diluted to a final concentration 1.35 or $1.15 \mu \mathrm{g} / \mathrm{ml}$ ( $4.0 \mathrm{ml}$ total volume), respectively, in a solution of $6 \%$ ethanol and $\mathrm{dd}_{2} \mathrm{O}$ by serial dilution. The Libby six-mix dilution was filtered through a $0.4 \mu \mathrm{m}$ Nucleopore Track-Etch membrane (Fisher Scientific, Pittsburgh, PA) followed by a rinse with $1 \mathrm{ml} \mathrm{100 \%}$ ethanol and drying overnight. Half of the dried filter was adhered to a standard aluminum specimen stub with colloidal silver paste (Electron Microscope Sciences, Hatfield, PA) followed by sputter coating with gold and palladium using a Polaron sputter coater (Model 5100; Quorum Technologies, East Sussex, UK). Images were acquired using a JEOL 6060 scanning electron microscope (JEOL USA, Inc., Peabody, MA) following a randomized design of field selection to obtain representative images of the sample. In order to determine interactions between cells and Libby six-mix, cells were grown on Thermonox plastic cover slips (Nalgen Nunc International, Naperville, IL), exposed to $75 \times 10^{6} \mu \mathrm{m}^{2} / \mathrm{cm}^{2}$ Libby six-mix for $24 \mathrm{~h}$, and then processed for SEM as described previously [52].

\section{Cell Viability}

After $24 \mathrm{~h}$, cells were collected with Accutase cell detachment reagent, and final cell suspensions in Accutase complete medium/HBSS were mixed with $0.4 \%$ trypan blue stain, a diazo dye which is retained by dead cells and excluded by viable cells. After $5 \mathrm{~min}$, unstained viable cells were counted using a hemocytometer to determine the total number of viable cells per dish. Based on the results of cell viability studies, Libby sixmix was evaluated in LP9/TERT-1 mesothelial cells at 
both low and high concentrations $\left(15 \times 10^{6}\right.$ and $75 \times 10^{6}$ $\mu \mathrm{m}^{2} / \mathrm{cm}^{2}$, respectively) at 8 and $24 \mathrm{~h}$ for the majority of assays. However, for gene profiling experiments employing microarrays, Libby six-mix was tested at the nontoxic concentration of $15 \times 10^{6} \mu^{2} / \mathrm{cm}^{2}$ only. Control groups typically included a negative control consisting of cells maintained in medium alone and a control consisting of cells exposed to the non-pathogenic glass beads at surface area concentrations equaling the highest Libby six-mix concentration utilized.

\section{RNA Preparation and Microarrays}

Total RNA was prepared using an RNeasy ${ }^{\circ}$ Plus Mini Kit according to the manufacturers' protocol (Qiagen, Valencia, CA), as published previously [53]. Microarrays were performed on samples from 3 independent experiments. For each experiment, $\mathrm{n}=3$ dishes were pooled into one sample per treatment group giving a total of $\mathrm{n}=3$ RNA samples per group. All procedures were performed by the Vermont Cancer Center DNA facility using a standard Affymetrix protocol as described previously [53,54]. GeneChip Human Genome U133A 2.0 arrays (Affymetrix, Santa Clara, CA) targeting 18,400 human transcripts were scanned twice (Hewlett-Packard GeneArray Scanner), the images overlaid, and the average intensities of each probe cell compiled. Microarray data were analyzed using GeneSifter software (VizX Labs, Seattle, WA). This program used a $t$-test for pairwise comparison and a Benjamini-Hochberg test for false discovery rate (FDR 5\%) to adjust for multiple comparisons. A 2-fold cutoff limit was used for analysis.

\section{Quantitative Real Time PCR (qRT-PCR)}

Total RNA $(1 \mu \mathrm{g})$ was reverse-transcribed with random primers using the AMV Reverse Transcriptase kit (Promega, Madison, WI) according to the recommendations of the manufacturer, as described previously [53]. To quantify gene expression, the cDNA was amplified by TaqMan $^{\circ}$ qRT-PCR using the 7700 Sequence Prism Detector (Perkin Elmer Applied Biosystems, Foster City, CA). Fold change in the genes of interest was calculated using the $\Delta \Delta C_{t}$ method. Duplicate assays were performed with RNA samples isolated from at least 3 independent experiments. The values obtained from cDNAs and hypoxanthine phosphoribosyl transferase (hprt) controls provided relative gene expression levels for the gene locus investigated. The Assays-On-Demand ${ }^{\mathrm{m} m}$ primer and probe sets used for all qRT-PCR experiments were purchased from Applied Biosystems (Foster City, CA).

\section{Western Blots}

Cells were exposed to agents as described above, the medium aspirated, and cells washed three times with ice-cold PBS prior to collection in $4 \mathrm{X}$ sample buffer
(200 $\mu \mathrm{M}$ Tris, $\mathrm{pH} 6.8,4 \% \mathrm{SDS}, 4 \mathrm{mg} / \mathrm{ml} \beta$-mercaptoethanol, $40 \%$ glycerol, $2 \mu \mathrm{M}$ pyronin-Y). The amount of protein was determined using the RC DC protein assay (Bio-Rad, Hercules, CA). A total of $30 \mu \mathrm{g}$ of protein was separated by $10 \%$ SDS-PAGE and transferred to nitrocellulose. Western blots were performed as described previously [55], using antibodies specific to SOD1 (rabbit polyclonal, 1:1000, $18 \mathrm{kDa}$ molecular weight (MW); Cell Signaling Technology, Danvers, MA), SOD2 (goat polyclonal, 1:200, 25 kDa MW; Santa Cruz Biotechnology, Inc., Santa Cruz, CA), and $\beta$-Actin (mouse monoclonal, 1:2000, 42 kDA MW; Abcam, Cambridge, MA). Quantity One ${ }^{\bullet}$ v.4.4.1 software (BioRad) was used to quantify band density, and values were normalized to $\beta$-Actin protein levels.

\section{SOD Activity Assays}

Cells were washed three times with ice-cold PBS and collected in $500 \mu \mathrm{l}-1 \mathrm{ml}$ of cold buffer (20 mM 4-(2hydroxyethyl)-1-piperazineethanesulfonic acid (HEPES), $1 \mathrm{mM}$ ethylene glycol tetraacetic acid (EGTA), $210 \mathrm{mM}$ mannitol, and $70 \mathrm{mM}$ sucrose, $\mathrm{pH}$ 7.2). Cells were then sonicated $5 \times 2 \mathrm{sec}$, centrifuged at $1500 \times \mathrm{g}$ at $4^{\circ} \mathrm{C}$ for $10 \mathrm{~min}$ and supernatants removed. These supernatants were subsequently used to conduct the SOD activity assay according to the manufacturer's protocol (Superoxide Dismutase Assay Kit; Cayman Chemical Company, Ann Arbor, MI). In order to assay MnSOD (SOD2) activity specifically, $3 \mathrm{mM}$ potassium cyanide $(\mathrm{KCN})$ was added to the reactions to inhibit both $\mathrm{Cu} / \mathrm{ZnSOD}$ (SOD1) and extracellular SOD (SOD3). Total protein concentrations in supernatants were also determined using the Bio-Rad Protein Assay so that final SOD activities could be represented as Units/ $\mu$ g protein.

\section{DCFDA Assays}

Following treatment, the cell medium was removed and replaced with DMEM/F-12 (1:1) medium without phenol red (GIBCO, Carlsbad, CA) supplemented as described previously and containing $0.5 \mu \mathrm{M}$ 5-(and-6)chloromethyl-2',7'-dichlorodihydrofluorescein diacetate, acetyl ester (CM- $\mathrm{H}_{2} \mathrm{DCFDA}$; Invitrogen, Carlsbad, CA). Cells were incubated in this medium for $15 \mathrm{~min}$ in the dark at $37^{\circ} \mathrm{C}$ and then trypsinized. Following neutralization with fully supplemented DMEM/F-12 (1:1) medium (without phenol red), cells were collected and spun for $4 \mathrm{~min}$ at $1200 \mathrm{rpm}$ at $4^{\circ} \mathrm{C}$ to generate a cell pellet. This pellet was washed and subsequently resuspended in 800 $\mu \mathrm{l}$ of 1X HBSS without phenol red (GIBCO, Carlsbad, CA). Samples containing asbestos were filtered through $50 \mu \mathrm{m}$ nylon mesh prior to being read on a Beckman Coulter Epics XL flow cytometer (Beckman Coulter, Inc., Brea, CA). Flow cytometry data was analyzed and histograms generated using WinMDI 2.8 software. For 
DCFDA visualization studies, treated cells were visualized on an Olympus IX70 inverted microscope immediately following DCFDA exposure to produce either phase contrast or fluorescent images $(460-495 \mathrm{~nm} / 510$ $\mathrm{nm}$ excitation/emission). Fluorescent microscope images were pseudocolored green. To determine whether DCFDA was exclusively localized in cells with shrunken nuclei, i.e., apoptotic or necrotic, cells were incubated at $37^{\circ} \mathrm{C}$ for $15 \mathrm{~min}$ in $1 \mathrm{ug} / \mathrm{mL}$ of Hoechst 33342 nuclear stain (Invitrogen, Carlsbad, CA) in DMEM/F-12 (1:1) medium with phenol red containing $0.5 \%$ FBS. Cells were then washed in medium and incubated at $37^{\circ} \mathrm{C}$ for $15 \mathrm{~min}$ in medium with $0.5 \mu \mathrm{M}$ DCFDA in the dark. Nuclear stain (350 nm/461 nm excitation/emission) and DCFDA (460-495 nm/510 nm excitation/emission) were imaged on an Olympus IX70 inverted microscope with the nuclei pseudocolored red and DCFDA pseudocolored green.

\section{Reduced Glutathione (GSH) Assay}

Treated cells were washed three times with ice-cold PBS, incubated on ice in $200 \mu \mathrm{l}$ of $1 \mathrm{X}$ cell lysis buffer (Cell Signaling Technology, Danvers, MA) containing 1 mM PMSF, and collected using a cell lifter. Cells were then centrifuged at $14000 \times \mathrm{g}$ at $4^{\circ} \mathrm{C}$ and supernatants removed and derivitized. Derivitization and high performance liquid chromatography (HPLC) detection of reduced glutathione (GSH) were performed as described previously [24]. The Bio-Rad Protein Assay (Bio-Rad Laboratories, Hercules, CA) was performed on supernatants as well to determine total protein concentration. GSH concentrations were subsequently divided by this protein concentration to obtain $\mathrm{nmol} \mathrm{GSH} / \mathrm{mg}$ protein. Final data are represented as the percent of GSH levels compared to untreated controls at each time point.

\section{Statistical Analysis}

Data from cell viability, western blotting, and SOD activity assays were evaluated by analysis of variance (ANOVA) using the Student Neuman-Keul's procedure for adjustment of multiple pair-wise comparisons between treatment groups. Glutathione depletion studies were analyzed via two-way ANOVA. Differences in gene expression values determined by qRT-PCR were evaluated using a Student's $t$-test. Differences with $\mathrm{p}$ values $<0.05$ were considered statistically significant.

\section{Acknowledgements}

This work was supported by a National Institute of Environmental Health Sciences training grant T32ES007122 to BTM and JMH. The authors thank the Vermont Cancer Center DNA Analysis Facility at the University of Vermont (Burlington, VT) for technical assistance with microarray analysis and qRT-PCR. We also acknowledge Milena Hristova for aid in conducting HPLC studies and Dr. Helmut Popper for contribution of the HKNM-2 normal human pleural mesothelial cells.

\section{Author details}

${ }^{1}$ Department of Pathology, University of Vermont College of Medicine, 89 Beaumont Avenue, Burlington, VT 05405, USA. ²Department of Medical Biostatistics, University of Vermont College of Medicine, 25 Carrigan Avenue, Burlington, VT 05405, USA. ${ }^{3}$ Department of Geological Sciences, University of Idaho, PO Box 443022, Moscow, ID 83843, USA.

\section{Authors' contributions}

$\mathrm{JMH}$ and BTM conceived of the overall research plan. MEG provided the Libby six-mix samples. SAL, TNP, and VA conducted SEM. AS and MBM aided in maintaining cell cultures, prepared RNA, and performed viability assays and microarray analysis. AvdV provided the protocol, reagents, and HPLC equipment to conduct the GSH depletion studies. JMH maintained cell cultures, interpreted the data, and performed the following: QRT-PCR, Western blotting, SOD activity assays, DCFDA assays and assays for GSH depletion. PMV performed statistical analyses on data sets. JMH and BTM drafted the manuscript. All authors read and approved the final manuscript.

\section{Competing interests}

The authors declare that they have no competing interests.

Received: 7 April 2010 Accepted: 11 September 2010

Published: 11 September 2010

\section{References}

1. Guthrie GD, Mossman BT: Health Effects of Mineral Dusts. Washington, D. C.: Mineralogical Society of America 1993.

2. Robinson BW, Lake RA: Advances in malignant mesothelioma. N Engl J Med 2005, 353:1591-1603.

3. United States Environmental Protection Agency Region 8 - Libby Site Background. [http://www.epa.gov/region8/superfund/libby/background. html].

4. Kelly J, Pratt GC, Johnson J, Messing RB: Community exposure to asbestos from a vermiculite exfoliation plant in NE Minneapolis. Inhal Toxicol 2006, 18:941-947.

5. Dixon G, Doria J, Freed J, Wood P, May I, Chambers T: Exposure assessment for asbestos-contaminated vermiculite. Washington, D.C.: United States Environmental Protection Agency, Office of Pesticides and Toxic Substances 1985, EPA 560/5-85-013.

6. Peipins LA, Lewin M, Campolucci S, Lybarger JA, Miller A, Middleton D, Weis C, Spence M, Black B, Kapil V: Radiographic abnormalities and exposure to asbestos-contaminated vermiculite in the community of Libby, Montana, USA. Environ Health Perspect 2003, 111:1753-1759.

7. Horton K, Kapil V, Larson T, Muravov O, Melnikova N, Anderson B: A review of the federal government's health activities in response to asbestoscontaminated ore found in Libby, Montana. Inhal Toxicol 2006, 18:925-940.

8. McDonald JC, Harris J, Armstrong B: Mortality in a cohort of vermiculite miners exposed to fibrous amphibole in Libby, Montana. Occup Environ Med 2004, 61:363-366.

9. Price B: Exposure to airborne amphibole structures and health risks: Libby, Montana. Regul Toxicol Pharmacol 2008, 52:S97-S109.

10. Whitehouse AC: Asbestos-related pleural disease due to tremolite associated with progressive loss of lung function: serial observations in 123 miners, family members, and residents of Libby, Montana. Am J Ind Med 2004, 46:219-225.

11. Whitehouse AC, Black CB, Heppe MS, Ruckdeschel J, Levin SM: Environmental exposure to Libby Asbestos and mesotheliomas. Am J Ind Med 2008, 51:877-880.

12. ATSDR: Health Consultation: Mortality from Asbestosis in Libby, Montana. Atlanta, GA: United States Department of Health and Human Services 2000.

13. ATSDR: Public Health Assessment: Libby Asbestos Site, Libby, Lincoln County, Montana. Atlanta, GA: United States Department of Health and Human Services 2003.

14. Shukla A, Gulumian M, Hei TK, Kamp D, Rahman Q, Mossman BT: Multiple roles of oxidants in the pathogenesis of asbestos-induced diseases. Free Radic Biol Med 2003, 34:1117-1129.

15. Hillegass J, Shukla A, MacPherson MB, Bond J, Steele C, Mossman BT: Utilization of gene profiling and proteomics to determine mineral 
pathogenicity in a human mesothelial cell line (LP9/TERT-1). J Toxicol Env Heal A 2010, 73:1-15.

16. Shukla A, MacPherson MB, Hillegass J, Ramos-Nino ME, Alexeeva V, Vacek PM, Bond JP, Pass HI, Steele C, Mossman BT: Alterations in gene expression in human mesothelial cells correlate with mineral pathogenicity. Am J Respir Cell Mol Biol 2009, 41:114-123.

17. Blake DJ, Bolin CM, Cox DP, Cardozo-Pelaez F, Pfau JC: Internalization of Libby amphibole asbestos and induction of oxidative stress in murine macrophages. Toxicol Sci 2007, 99:277-288.

18. Gunter ME, Dyar MD, Twamley B, Foit FF, Cornelius S: Composition, Fe3 +/Sigma Fe, and crystal structure of non-asbestiform and asbestiform amphiboles from Libby, Montana, USA. American Mineralogist 2003, 88:1970-1978.

19. Meeker GP, Bern AM, Brownfield IK, Lowers HA, Sutley SJ, Hoefen TM, Vance JS: The composition and morphology of amphiboles from the Rainy Creek complex, near Libby, Montana. American Mineralogist 2003, 88:1955-1969.

20. Wylie AG, Verkouteren JR: Amphibole asbestos from Libby, Montana: Aspects of nomenclature. American Mineralogist 2000, 85:1540-1542.

21. Sanchez MS, Gunter ME: Quantification of amphibole content in expanded vermiculite products from Libby, Montana USA using powder X-ray diffraction. American Mineralogist 2006, 91:1448-1451.

22. Campbell WJ, Huggins CW, Wylie AG: Chemical and physical characterization of amosite, chrysotile, crocidolite, and nonfibrous tremolite for oral ingestion studies by the National Institute of Environmental Health Sciences. Washington, DC: U.S. Department of the Interior, U.S. Bureau of Mines 1980.

23. Janssen YM, Marsh JP, Absher MP, Gabrielson E, Borm PJ, Driscoll K, Mossman BT: Oxidant stress responses in human pleural mesothelial cells exposed to asbestos. Am J Respir Crit Care Med 1994, 149:795-802

24. Shukla A, Flanders T, Lounsbury KM, Mossman BT: The gammaglutamylcysteine synthetase and glutathione regulate asbestos-induced expression of activator protein-1 family members and activity. Cancer Res 2004, 64:7780-7786.

25. Strieter RM, Koch AE, Antony VB, Fick RB Jr, Standiford TJ, Kunkel SL: The immunopathology of chemotactic cytokines: the role of interleukin-8 and monocyte chemoattractant protein-1. J Lab Clin Med 1994, 123:183-197.

26. Boylan AM, Ruegg C, Kim KJ, Hebert CA, Hoeffel JM, Pytela R, Sheppard D, Goldstein IM, Broaddus VC: Evidence of a role for mesothelial cell-derived interleukin 8 in the pathogenesis of asbestos-induced pleurisy in rabbits. J Clin Invest 1992, 89:1257-1267.

27. Griffith DE, Miller EJ, Gray LD, Idell S, Johnson AR: Interleukin-1-mediated release of interleukin-8 by asbestos-stimulated human pleural mesothelial cells. Am J Respir Cell Mol Biol 1994, 10:245-252.

28. Ilavska S, Jahnova E, Tulinska J, Horvathova M, Dusinska M, Wsolova L, Kyrtopoulos SA, Fuortes L: Immunological monitoring in workers occupationally exposed to asbestos. Toxicology 2005, 206:299-308.

29. Tulinska J, Jahnova E, Dusinska M, Kuricova M, Liskova A, llavska S, Horvathova M, Wsolova L, Kyrtopoulos SA, Collins A, et al: Immunomodulatory effects of mineral fibres in occupationally exposed workers. Mutat Res 2004, 553:111-124.

30. Pugnaloni A, Lucarini G, Giantomass IF, Lombardo L, Capella S, Belluso E, Zizzi A, Panico AM, Biagini G, Cardile V: In vitro study of biofunctional indicators after exposure to asbestos-like fluoro-edenite fibres. Cell Mol Biol (Noisy-le-grand) 2007, 53(Suppl):OL965-980.

31. Marrogi A, Pass HI, Khan M, Metheny-Barlow L, Harris CC, Gerwin BI: Human mesothelioma samples overexpress both cyclooxygenase-2 (COX-2) and inducible nitric oxide synthase (NOS2): in vitro antiproliferative effects of a COX-2 inhibitor. Cancer Res 2000, 60:3696-3700

32. Mossman BT, Marsh JP, Shatos MA: Alteration of superoxide dismutase activity in tracheal epithelial cells by asbestos and inhibition of cytotoxicity by antioxidants. Lab Invest 1986, 54:204-212.

33. Connor KM, Hempel N, Nelson KK, Dabiri G, Gamarra A, Belarmino J, Van De Water L, Mian BM, Melendez JA: Manganese superoxide dismutase enhances the invasive and migratory activity of tumor cells. Cancer Res 2007, 67:10260-10267.

34. Kahl R, Kampkotter A, Watjen W, Chovolou Y: Antioxidant enzymes and apoptosis. Drug Metab Rev 2004, 36:747-762.
35. Mantymaa P, Siitonen T, Guttorm T, Saily M, Kinnula V, Savolainen ER, Koistinen P: Induction of mitochondrial manganese superoxide dismutase confers resistance to apoptosis in acute myeloblastic leukaemia cells exposed to etoposide. Br J Haematol 2000, 108:574-581.

36. Mossman BT, Surinrut P, Brinton BT, Marsh JP, Heintz NH, Lindau-Shepard B, Shaffer JB: Transfection of a manganese-containing superoxide dismutase gene into hamster tracheal epithelial cells ameliorates asbestos-mediated cytotoxicity. Free Radic Biol Med 1996, 21:125-131.

37. Holley JA, Janssen YM, Mossman BT, Taatjes DJ: Increased manganese superoxide dismutase protein in type II epithelial cells of rat lungs after inhalation of crocidolite asbestos or cristobalite silica. Am J Pathol 1992, 141:475-485.

38. Janssen YM, Marsh JP, Absher MP, Hemenway D, Vacek PM, Leslie KO, Borm PJ, Mossman BT: Expression of antioxidant enzymes in rat lungs after inhalation of asbestos or silica. J Biol Chem 1992, 267:10625-10630.

39. Malafa M, Margenthaler J, Webb B, Neitzel L, Christophersen M: MnSOD expression is increased in metastatic gastric cancer. J Surg Res 2000, 88:130-134.

40. Janssen $A M$, Bosman $C B$, Kruidenier $L$, Griffioen $G$, Lamers $C B$, van Krieken $\mathrm{JH}$, van de Velde $\mathrm{CJ}$, Verspaget HW: Superoxide dismutases in the human colorectal cancer sequence. J Cancer Res Clin Oncol 1999, 125:327-335

41. Ray G, Batra S, Shukla NK, Deo S, Raina V, Ashok S, Husain SA: Lipid peroxidation, free radical production and antioxidant status in breast cancer. Breast Cancer Res Treat 2000, 59:163-170.

42. Kinnula VL, Pietarinen-Runtti P, Raivio K, Kahlos K, Pelin K, Mattson K, Linnainmaa $K$ : Manganese superoxide dismutase in human pleural mesothelioma cell lines. Free Radic Biol Med 1996, 21:527-532.

43. Kahlos K, Paakko P, Kurttila E, Soini Y, Kinnula VL: Manganese superoxide dismutase as a diagnostic marker for malignant pleural mesothelioma. Br J Cancer 2000, 82:1022-1029.

44. Kahlos K, Anttila S, Asikainen T, Kinnula K, Raivio KO, Mattson K, Linnainmaa $K$, Kinnula VL: Manganese superoxide dismutase in healthy human pleural mesothelium and in malignant pleural mesothelioma. Am J Respir Cell Mol Biol 1998, 18:570-580.

45. Landi S, Gemignani F, Neri M, Barale R, Bonassi S, Bottari F, Canessa PA, Canzian F, Ceppi M, Filiberti R, et al: Polymorphisms of glutathione-Stransferase $\mathrm{M} 1$ and manganese superoxide dismutase are associated with the risk of malignant pleural mesothelioma. Int I Cancer 2007, 120:2739-2743

46. Putnam EA, Smartt A, Groves A, Schwanke C, Brezinski M, Pershouse MA Gene expression changes after exposure to six-mix in a mouse model. J Immunotoxicol 2008, 5:139-144.

47. Smartt AM, Brezinski M, Trapkus M, Gardner D, Putnam EA: Collagen accumulation over time in the murine lung after exposure to crocidolite asbestos or Libby amphibole. Environ Toxicol 2009.

48. Zhao H, Kalivendi S, Zhang H, Joseph J, Nithipatikom K, Vasquez-Vivar J, Kalyanaraman B: Superoxide reacts with hydroethidine but forms a fluorescent product that is distinctly different from ethidium: potential implications in intracellular fluorescence detection of superoxide. Free Radic Biol Med 2003, 34:1359-1368.

49. Dickson MA, Hahn WC, Ino Y, Ronfard V, Wu JY, Weinberg RA, Louis DN, Li FP, Rheinwald JG: Human keratinocytes that express hTERT and also bypass a p16(INK4a)-enforced mechanism that limits life span become immortal yet retain normal growth and differentiation characteristics. Mol Cell Biol 2000, 20:1436-1447.

50. Bellamy JM, Gunter ME: Morphological characterization of Libby "six-mix" amphiboles used in in vivo studies. Periodico Di Mineralogia 2008, 77:75-82.

51. Campbell WJ, Huggins CW, Wylie AG: Chemical and physical characterization of amosite, chrysotile, crocidolite, and nonfibrous tremolite for oral ingestion studies. US Bureau of Mines Report of Investigations Washington, DC: National Institute of Environmental Health Sciences 1980

52. Blumen SR, Cheng K, Ramos-Nino ME, Taatjes DJ, Weiss DJ, Landry CC Mossman BT: Unique uptake of acid-prepared mesoporous spheres by lung epithelial and mesothelioma cells. Am J Respir Cell Mol Biol 2007, 36:333-342.

53. Shukla A, Lounsbury KM, Barrett TF, Gell J, Rincon M, Butnor KJ, Taatjes DJ, Davis GS, Vacek P, Nakayama Kl, et al: Asbestos-induced peribronchiolar 
cell proliferation and cytokine production are attenuated in lungs of protein kinase C-delta knockout mice. Am J Pathol 2007, 170:140-151.

54. Sabo-Attwood T, Ramos-Nino M, Bond J, Butnor KJ, Heintz N, Gruber AD, Steele C, Taatjes DJ, Vacek P, Mossman BT: Gene expression profiles reveal increased $\mathrm{mClca} 3$ (Gob5) expression and mucin production in a murine model of asbestos-induced fibrogenesis. Am J Pathol 2005, 167:1243-1256.

55. Shukla A, Barrett TF, Nakayama Kl, Nakayama K, Mossman BT,

Lounsbury KM: Transcriptional up-regulation of MMP12 and MMP13 by asbestos occurs via a PKCdelta-dependent pathway in murine lung. Faseb J 2006, 20:997-999.

doi:10.1186/1743-8977-7-26

Cite this article as: Hillegass et al: Mechanisms of oxidative stress and alterations in gene expression by Libby six-mix in human mesothelial cells. Particle and Fibre Toxicology 2010 7:26.

\section{Submit your next manuscript to BioMed Central} and take full advantage of:

- Convenient online submission

- Thorough peer review

- No space constraints or color figure charges

- Immediate publication on acceptance

- Inclusion in PubMed, CAS, Scopus and Google Scholar

- Research which is freely available for redistribution

Submit your manuscript at www.biomedcentral.com/submit
Ciomed Central 